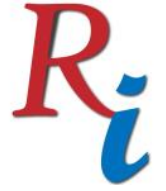

Asia Proceedings of Social Sciences

(APSS)

www.readersinsight.net/APSS

\title{
Problems faced by the Street Market Stakeholders: Malaysian Case Study
}

\section{Nur Atiqah Rochin Demong*}

Faculty of Business and Management, Universiti Teknologi MARA, Cawangan Selangor, Kampus Puncak Alam, 42300 Selangor,

Malaysia

\section{Erne Suzila Kassim}

Faculty of Business and Management, Universiti Teknologi MARA, Cawangan Selangor, Kampus Puncak Alam, 42300 Selangor,

Malaysia

\section{Melissa Shahrom}

Faculty of Business and Management, Universiti Teknologi MARA, Cawangan Selangor, Kampus Puncak Alam, 42300 Selangor, Malaysia

\section{Noor'ain Mohamad Yunus}

Faculty of Business and Management, Universiti Teknologi MARA, Cawangan Selangor, Kampus Puncak Alam, 42300 Selangor, Malaysia

\section{Sri Fatiany Abdul Kader Jailani}

Faculty of Business and Management, Universiti Teknologi MARA, Cawangan Selangor, Kampus Puncak Alam, 42300 Selangor,

Malaysia

*Corrosponding author's Email: rochin@puncakalam.uitm.edu.my

Peer-review under responsibility of $4^{\text {th }}$ Asia International Conference 2018 editorial board (http://www.utm.my/asia/our-team/) (C) 2018 Published by Readers Insight Publisher, lat 306 Savoy Residencia, Block 3 F11/1,44000 Islamabad. Pakistan, info@ readersinsight.net

This is an open access article under the CC BY-NC-ND license (http://creativecommons.org/licenses/by-nc-nd/4.0/). 


\section{Research Highlights}

Street market is considered as an informal business activity. Some of the famous street markets are Bangkok's Chatuchak Weekend Market, Souks of Marrakesh, Taipei's Shilin Street market and Barcelona's La Boqueria (Momondo, 2013). Street market stalls and trucks can be found almost everywhere either in housing as well as commercial areas approved by local authorities. One of the Malaysian initiatives in promoting for a well-balanced retail and micro-enterprise ecosystem is by transforming the street markets distribution and operation via the Malaysian NKEA (National Key Economic Area) (Kemubu Agriculture Development Authorithy, 2018). Stakeholders of street market includes of street vendor (seller), customer (buyer) and local authorities. The findings of the interviews with the respective local council, and street market vendors and customers showed that price non-standardization, service quality, product preference, infrastructure, convenience and accessibility and sellers' resistance to change are the key issues. In addition, the street markets could be considered as business incubators for aspiring entrepreneurs since they would need to put in a very small investment to start the business, the risk of failure was minimal, and there was the opportunity to earn a hefty income (Salleh, Yaakub, Yunus, \& Wan Sulong, 2012).

\section{Graphical A bstract}

\section{Local Council}

-Street vendor's unwillingness to change

- Misapply of license

- Illegal street vendors

\section{Street Vendors (Sellers)}

- Buyer's product preference

- Infrastructure and facility - limited space

- Competitions from giant retailers (Tesco, Giant, Checkers)

-Operation time restriction

\section{Customer (Buyers)}

- Price non-standardisation

- Service quality

- Product preference

- Convenience and accessibility 


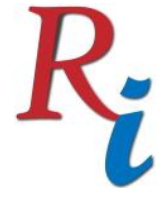

Asia Proceedings of Social Sciences

(APSS)

www.readersinsight.net/APSS

\section{Research Objectives}

The study is based on the following two major objectives namely, to examine the problems faced by the street market stakeholders in Malaysia and to understand the role and perception of street market stakeholders in Malaysia. Street market business is playing a dominating role in providing employment and income generation.

\section{Methodology}

Action Research (AR) method employed to answer the research objectives of the study. This research method is well suited in the area of information systems development. AR is a combination of action and research and committed to the production of new knowledge by seeking solutions or improvements to real life practical situations (McKay \& Marshall, 2001). There are two stages involves in this proposed study namely diagnostic stage and therapeutic stage (Baskerville \& Myers, 2004).

The methods adopted in this research were comprise firstly, the collection and analysis of audio-visual materials, reports, documents and other statistics from street market stakeholders. Data collected based on document analysis were both quantitative and qualitative in nature. Second, through the use of a survey instrument designed and administered in face to face interviews with select personnel, basic information on surveyed entities compiled and analysed. Third, personal semi-structured interviews were conducted that provide detailed qualitative information on specific and social wellbeing-relevant matters.

\section{Results}

The results of the study can be divided into three different types of street market stakeholders namely, local authorities, street vendors (sellers) and the customers (buyers). The street market is under the jurisdiction of the local council specifically under the licensing department responsible for various types of market (street market, farmers market, day 


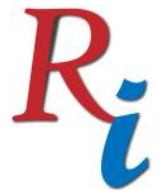

\section{Asia Proceedings of Social Sciences \\ (APSS) \\ www.readersinsight.net/APSS}

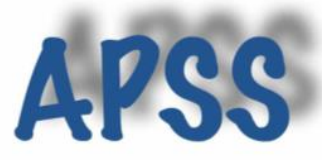

market and main market). The local council collaborates with the health department to ensure that the traders/operators meet the specific guidelines. If the traders failed to meet the stipulated conditions, they would be fined and a warning letter will be issued and if they fail to comply with the regulations, their license/permits will be revoked. The common issues faced by the local council are sellers' resistance to change, illegal street vendors and misapply of the business license. For sellers, four main issues emerged namely buyer's product preference, infrastructure, location and facility specifically limited space provided, competition form giant retailers such as Tesco/Giant and restriction of operation time. There are four main issues from the viewpoint of the customers namely price non-standardisation, convenience and accessibility, service quality and product preferences. All informants indicated that convenience and accessibility are the main issues of the street market in Malaysia.

\section{Findings}

The findings of the study provide the evidences for the key problems faced by local council, street market vendors and the customer generally the society. They serve as the foundations of understanding how the next process of street market in Malaysia should be conducted. The results and the experience of this study clearly demonstrate the link between local council, buyers and sellers as the primary stakeholders who need to be integrated especially information pertinent to all stakeholders. In addition, it also shows the importance of understanding communication, partnership and linkage intensification among the stakeholders for the respective authority to deal with the situation.

\section{Acknowledgement}

The authors would like to acknowledge Universiti Teknologi MARA, Cawangan Selangor, Puncak Alam Campus for funding the study via Dana UCS (600-UITMSEL (PI. 5/4) (032/2018). 


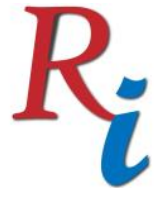

Asia Proceedings of Social Sciences

(APSS)

www.readersinsight.net/APSS

\section{References}

Baskerville, R., \& Myers, M. D. (2004). Special issue on action research in information systems: Making IS research relevant to practice: Foreword. MIS Quarterly, 329-335.

Kemubu Agriculture Development Authorithy. (2018). NATIONAL KEY ECONOMIC AREA (NKEA). Retrieved from http://kada.gov.my/en/bidang-ekonomiutama-negara-nkea

McKay, J., \& Marshall, P. (2001). The dual imperatives of action research. Information Technology \& People. 14(1), 46-59.

Momondo. (2013). 10 great traditional markets around the world. Retrieved from https://www.momondo.com/discover/article/10-great-traditional-marketsaround-the-world

Salleh, F., Yaakub, N., Yunus, K., \& Wan Sulong, W. K. (2012). Factors Influencing the Night Market Traders' Performance in Malaysia. International Journal of Business and Management, 7(14). 